\title{
KAJIAN KONSEP KENYAMANAN JALUR PEDESTRIAN DI JL. STASIUN KERETA API MEDAN DAN JL. PALANG MERAH MEDAN
}

\author{
Eli Mastoni ${ }^{(1)}$, Nicolaus Simamora ${ }^{(2)}$, Yulianto $^{(3)}$
}

\author{
(1) Mahasiswa, Prodi Arsitektur, Fakultas Teknik, Universitas Katolik Santo Thomas Sumatera Utara \\ (2) Staff Pengajar, Prodi Arsitektur, Fakultas Teknik, Universitas Katolik Santo Thomas Sumatera Utara \\ (3) Staff Pengajar, Prodi Arsitektur, Fakultas Teknik, Universitas Katolik Santo Thomas Sumatera Utara \\ Email: yulianto@ust.ac.id
}

\begin{abstract}
Pedestrian paths are very important in urban design elements, especially trade areas. Similarly on Jl. Medan Railway Station and Jl. Medan Red Cross, but this need is not comparable to the conditions of the pedestrian path on both roads which have been damaged and not maintained, causing inconvenience. Because of this, the researchers tried to find the concept of the pedestrian path to the two roads. The research method used is a qualitative descriptive method. Then the method is analyzed based on theoretical and empirical analysis. Through the theoretical analysis and empirical analysis found several results in accordance with the hypothesis of the researcher. The results of the analysis are then made an appropriate concept on Jl. Medan Railway Station and Jl. Medan Red Cross.
\end{abstract}

Keywords: Path, Comfort, Pedestrian Concept

\begin{abstract}
Abstrak
Jalur pedestrian adalah jalur sirkulasi untuk pejalan kaki yang sarat dengan pemakai, terlebih lagi jika jalur pedestrian bisa menjamin keamanan dan kenyamanan pejalan kaki. Jalur pedestrian sangat penting sekali dalam elemen desain perkotaan, khususnya kawasan-kawasan perdagangan. Demikian pula di Jl. Stasiun Kereta Api Medan dan Jl. Palang Merah Medan, namun kebutuhan ini tidak sebanding dengan kondisi jalur pedestrian di kedua jalan tersebut yang telah rusak dan tidak terawat sehingga menyebabkan ketidaknyamanan. Karena hal tersebut peneliti mencoba menemukan konsep jalur pedestrian terhadap kedua jalan tersebut. Metode penelitian yang digunakan merupakan metode deskriptif kualitatif. Selanjutnya metode tersebut dianalisis berdasarkan analisis teoritis dan empiris. Melalui analisis teoritis dan analisis empiris tersebut ditemukan beberapa hasil yang sesuai dengan hipotesa peneliti. Hasil analisis tersebut selanjutnya dibuat suatu konsep yang sesuai di Jl. Stasiun Kereta Api Medan dan Jl. Palang Merah Medan.
\end{abstract}

Kata-kunci : Jalur, Kenyamanan, Konsep, Pedestrian

\section{Pendahuluan}

Jalur pedestrian adalah jalur sirkulasi untuk pejalan kaki. Jalur ini umumnya sarat dengan pemakai, terlebih lagi jika jalur pedestrian bisa menjamin keamanan dan kenyamanan pejalan kaki. Jalur pedestrian sangat penting sekali dalam elemen desain perkotaan, khususnya kawasan-kawasan perdagangan. Dengan berjalan kaki, pejalan kaki mendapat informalsi dan pengenalan yang lebih detail terhadap informalsi disekitarnya. Jl. Stasiun Kereta Api Medan dan Jl. Palang Merah Medan merupakan dua jalur pedestrian disekitar Lapangan Merdeka Medan yang menghubungkan beberapa jalur lain yang sangat penting dalam perdagangan.

Namun, banyaknya perkerasan yang rusak, fasilitas pendukung aktivitas yang tidak tersedia, serta fungsi-fungsi yang disalah gunakan telah mengganggu kenyamanan aktivitas berjalan kaki dari kedua jalur 
tersebut. Oleh sebab itu, perlu ditemukan suatu konsep yang sesuai untuk meningkatkan kenyamanan jalur pedestrian di Jl. Stasiun Kereta Api Medan dan Jl. Palang Merah Medan tersebut.

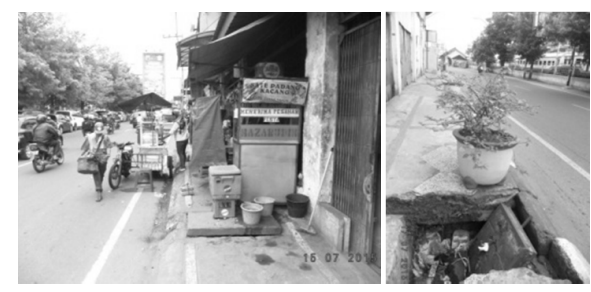

Gambar 1. Kondisi jalur pedestrian di Jl. Stasiun Kereta Api Medan

\section{Kajian Pustaka}

Shirvani (1985) berpendapat bahwa hal yang penting dalam menghadapi permasalahan jalur pedestrian selain fungsi dan kebutuhan adalah kenyamanan psikologis dan kenyamanan fisik. Fungsi dan kebutuhan pedestrian yang memadai merupakan bagian dari pemecahan desain, termasuk pertimbangan kelayakan terhadap sirkulasi, pencapaian, informalsi, dan kenyamanan.

Menurut Rubenstein (dalam Mirsa, 2012), tujuan adanya jalur pedestrian adalah untuk kesejahteraan, keamanan, kemudahan, kenyamanan, dan keindahan. Prinsip struktur jalur pedestrian adalah dapat memberikan prioritas utama pengembangan area pejalan kaki yang dapat memberikan keamanan pejalan kaki dalam melakukan aktivitas dan melindunginya dari gangguan kendaraan bermotor. Rubenstein lebih lanjut menyatakan bahwa hal utama yang diperhatikan dalam pengembangan sirkulasi pejalan kaki adalah rasa aman, kenyamanan, dan estetika.

Shirvani (1985) juga mengatakan bahwa jalur pedestrian sangat perlu sekali dalam elemen desain perkotaan, khususnya pada kawasan-kawasan perdagangan. Sebuah sistem pedestrian yang baik mengurangi ketergantungan dari kendaraan bermotor di area pusat kota, menambah pengguna pejalan kaki di pusat kota, memperbesar lingkungan yang mengajukan dalam sistem skala manusia, menciptakan beberapa aktivitas retail, dan akhirnya membantu untuk meningkatkan kualitas udara. Pertumbuhan yang ditekankan pada skema jalur pedestrian dibanyak kota mengilustrasikan hal tersebut cukup baik dalam pertumbuhan kota tersebut.

Carr (dalam Mirsa, 2012), menyebutkan bahwa jalur pedestrian (pedestrian sidewalks) adalah bagian dari kota dimana orang bergerak dengan kaki, biasanya sepanjang sisi jalan baik yang direncanakan ataupun yang terbentuk dengan sendirinya, menghubungkan suatu tempat dengan tempat lainnya.

\section{Metode Penelitian}

Metode penelitian yang digunakan ialah metode penelitian kualitatif yang bersifat deskriptif. Metode pengumpulan data yang dilakukan ialah observasi, pengukuran, dokumentasi, dan daftar pertanyaan (kuestioner). Teknik analisis data yang dilakukan menggunakan pembobotan dan tabulasi. Pembobotan digunakan dalam analisis teoritis sedangkan tabulasi digunakan dalam analisisis empiris (kuestioner). Metode penelitian yang bersifat deskriptif dilakukan untuk menjelaskan keadaan yang terjadi di Jl. Stasiun Kereta Api Medan dan Jl. Palang Merah Medan.

\section{Observasi}

Pengamatan (observasi), yaitu teknik pengumpulan data melalui pengamatan langsung kepada objek penelitian. Observasi sebagai teknik pengumpulan data mempunyai ciri yang spesifik bila dibandingkan dengan teknik yang lain, yaitu wawancara dan dokumentasi. Observasi tidak terbatas pada manusia, tetapi juga objek-objek alam yang lain. 


\section{Pengukuran}

Pengukuran yang dilakukan dilapangan ialah pengukuran lebar jalan, trotoar, serta jumlah pengguna jalur pedestrian (trotoar) di Jl. Stasiun Kereta Api Medan dan Jl. Palang Merah Medan. Pengukuran dilakukan selama beberapa hari, hari yang diambil ialah hari biasa dan hari libur (pada saat pengamatan bertepatan dengan idul fitri). Interval waktu yang diambil ialah setiap satu jam dilakukan pada pukul 09.00-10.00 WIB, 12.00-13.00 WIB, 16.00-17.00 WIB, dan 18.00-19.00 WIB.

\section{Dokumentasi}

Dokumentasi ini dilakukan untuk melengkapi dan menambah validitas data yang diperoleh melalui pengamatan, penggambaran, pengukuran, dan pemetaan. Sumber informalsi yang didokumentasikan adalah sumber informalsi yang sangat penting dan dapat menggambarkan bagaimana kondisi di Jl. Stasiun Kereta Api Medan dan Jl. Palang Merah Medan.

\section{Daftar Pertanyaan (Kuestioner)}

Kuestioner adalah proses pengumpulan data melalui daftar pertanyaan. Keterangan-keterangan yang diperoleh dengan teknik schedule yakni pencatat membawakan daftar isian pertanyaan kepada responden dengan cara bertatap muka secara langsung, selanjutnya pencatat mengisikan poin-poin yang telah dijawabkan oleh responden.

Daftar pertanyaan yang disusun bertujuan untuk mengetahui pengalaman, pendapat, serta perasaan pejalan kaki tentang 8 faktor kenyamanan di Jl. Stasiun Kereta Api Medan dan Jl. Palang Merah Medan. Jumlah responden diambil berdasarkankan jumlah segmen jalan yang telah dibagi yaitu 4 segmen jalur pedestrian, jumlah responden sendiri diambil sebanyak 5 responden dalam satu segmen sehingga jumlah responden yang dilakukan wawancara sebanyak 20 responden. Hal yang menjadi kesulitan saat memberikan daftar pertanyaan adalah kurangnya antusiasme dari pejalan kaki untuk memberikan pendapat kepada pengamat saat melakukan wawancara dengan teknik schedule ini. Hal ini disebabkan oleh kebanyakan dari pejalan kaki memiliki kegiatan yang tidak bisa ditinggalkan sehingga tidak bisa memberikan waktu untuk dilakukan wawancara.

\section{Metode Analisis Data}

Dalam menemukan permasalahan kenyamanan di Jl. Stasiun Kereta Api Medan dan Jl. Palang Medan, analisis data yang dilakukan ialah analisis kualitatif melalui proses pembobotan dan tabulasi, hal ini dilakukan untuk menilai kondisi fisik dari Jl. Stasiun Kereta Api Medan dan Jl. Palang Merah Medan tersebut. Kriteria pembobotan dan tabulasi didasari atas 8 faktor kenyamanan jalur pedestrian yakni :

1. Sirkulasi,

2. Iklim/kekuatan alam,

3. Kebisingan,

4. Aroma/bau-bauan,

5. Bentuk,

6. Keamanan,

7. Kebersihan, dan

8. keindahan

\section{Pembobotan}

Pembobotan ialah proses melakukan penilaian berdasarkan ukuran atau standar mengenai jalur pedestrian. Untuk mendapatkan hasil pembobotan, beberapa kriteria jawaban diberikan nilai sehingga mempermudah dalam proses pembobotan. Nilai pembobotan yang dilakukan adalah sebagai berikut: 
Tabel 1. Nilai Pembobotan

\begin{tabular}{ll}
\hline keadaan & bobot \\
\hline Sangat baik/nyaman/aman/bersih & 3 \\
\hline Baik/nyaman/aman/bersih & 2 \\
\hline Cukup baik/nyaman/aman/bersih & 1 \\
\hline Tidak baik/nyaman/aman/bersih & -1 \\
\hline Sangat tidak aik/nyaman/aman/bersih & -2 \\
\hline
\end{tabular}

Dari hasil pembobotan tersebut diambil nilai rata-rata dari faktor kenyamanan berdasarkan studi literatur (teori-teori jalur pedestrian) yang dilakukan yang selanjutnya diambil suatu kesimpulan. Teknik penilaian yang dilakukan adalah sebagai berikut:

\begin{tabular}{|c|c|}
\hline \multirow[t]{4}{*}{ FAKTOR KENYAMANAN = } & JUMLAH BOBOT \\
\hline & $\overline{J U M L A H}$ \\
\hline & FAKTOR \\
\hline & KENYAMANAN \\
\hline
\end{tabular}

Tabel 2. Nilai Rata-rata Pembobotan

\begin{tabular}{ccc}
\hline $\begin{array}{c}\text { NILAI } \\
\text { RATA- } \\
\text { ATA }\end{array}$ & PENILAIAN & KET: \\
\hline $3 \mathrm{~s} / \mathrm{d} 2$ & Sangat & $\mathrm{SN}$ \\
& Baik/Nyaman/Aman/Bersih & \\
\hline $2 \mathrm{~s} / \mathrm{d} 1$ & Baik/Nyaman/Aman/Bersih & $\mathrm{N}$ \\
\hline $1 \mathrm{~s} / \mathrm{d} 0$ & Cukup & $\mathrm{CN}$ \\
& Baik/Nyaman/Aman/Bersih \\
\hline $0 \mathrm{~s} / \mathrm{d}-1$ & Tidak & $\mathrm{TN}$ \\
& Baik/Nyaman/Aman/Bersih \\
\hline$-1 \mathrm{~s} / \mathrm{d}-2$ & Sangat Tidak & $\mathrm{STN}$ \\
& Baik/Nyaman/Aman/Bersih \\
\hline
\end{tabular}

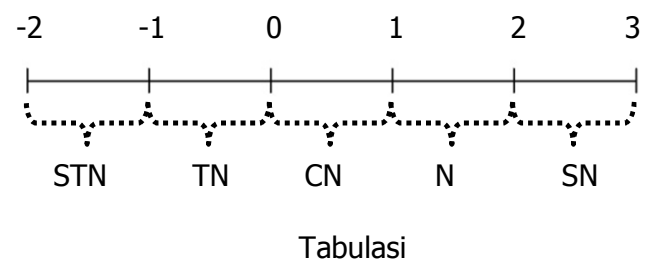

Pendapat para responden yang berhasil diperoleh, dikumpulkan berdasarkan daftar pertanyaan yang telah dibuat. Selanjutnya dilakukan penilaian subjektif dengan cara membuat tabel terhadap pilihan para responden. Dari pilihan jawaban responden tersebut, diambil suatu pilihan jawaban terbanyak sebagai 
suatu kesimpulan terhadap kondisi di Jl. Stasiun Kereta Api Medan dan Jl. Palang Merah Medan. Contoh salah satu tabel tersebut adalah sebagai berikut:

Tabel 3. Faktor Sirkulasi

\begin{tabular}{|c|c|}
\hline Pertanyaan & Jawaban Responden $\quad$ Jlh \\
\hline \multirow{5}{*}{$\begin{array}{l}\text { Bagaimanakah pendapat } \\
\text { anda mengenai } \\
\text { keberadaan parkir liar, dan } \\
\text { pedagang kaki lima ( } P K L) \\
\text { di jalan ini? }\end{array}$} & Sangat Nyaman \\
\hline & Nyaman \\
\hline & Cukup Nyaman \\
\hline & Tidak Nyaman \\
\hline & $\begin{array}{l}\text { Sangat } \\
\text { Nyaman }\end{array}$ \\
\hline
\end{tabular}

\section{Analisis dan Interpretasi}

Melalui metode tersebut, hasil analisis yang diperoleh adalah sebagai berikut:

Tabel 4. Hasil pembobotan melalui analisis teoritis (kajian pengamat berdasarkan teori-teori jalur pedestrian)

\begin{tabular}{|c|c|c|c|c|c|c|c|c|}
\hline \multirow[t]{3}{*}{ No } & \multirow{3}{*}{$\begin{array}{l}\text { FAKTOR } \\
\text { KENYAMANA } \\
\mathrm{N}(\mathrm{F})\end{array}$} & \multicolumn{4}{|c|}{ ANALISA KASUS (A) } & \multirow{3}{*}{$\begin{array}{l}\text { NILAI } \\
\text { TOTAL } \\
(\mathrm{NT})=\mathrm{FxA}\end{array}$} & \multirow{3}{*}{$\begin{array}{l}\text { NILAI RATA- } \\
\text { RATA (NR) } \\
=N T / A\end{array}$} & \multirow[t]{3}{*}{ KESIMPULAN } \\
\hline & & \multicolumn{4}{|c|}{ Segmen } & & & \\
\hline & & A & $\mathrm{B}$ & $\mathrm{C}$ & $\mathrm{D}$ & & & \\
\hline 01 & Sirkulasi & 0 & 0,25 & 1,75 & 0,25 & 2,25 & 0,56 & $\mathrm{CN}$ \\
\hline 02 & $\begin{array}{l}\text { Iklim atau } \\
\text { Kekuatan } \\
\text { Alam }\end{array}$ & 0 & 0,5 & 0,5 & $-0,5$ & 0,5 & 0,13 & $\mathrm{CN}$ \\
\hline 03 & Kebisingan & $-0,6$ & $\begin{array}{l}- \\
0,33\end{array}$ & 1 & 0,66 & 0,73 & 0,18 & $\mathrm{CN}$ \\
\hline 04 & $\begin{array}{l}\text { Aroma atau } \\
\text { Bau-bauan }\end{array}$ & 0,6 & 0,33 & $\begin{array}{l}- \\
0,66\end{array}$ & $-1,66$ & $-1,39$ & $-0,35$ & TN \\
\hline 05 & Bentuk & 1,2 & 0,83 & 0,33 & $-0,16$ & 2,2 & 0,55 & $\mathrm{CN}$ \\
\hline 06 & Keamanan & 0,5 & $-0,5$ & 1,5 & 1,5 & 3 & 0,75 & $\mathrm{CN}$ \\
\hline 07 & Kebersihan & -2 & -2 & -2 & -1 & -7 & $-1,75$ & STN \\
\hline 08 & Keindahan & -1 & -1 & -1 & 1 & -2 & $-0,5$ & TN \\
\hline NIL & I TOTAL $(\mathrm{X})$ & $-1,3$ & $-1,92$ & 1,42 & 0.09 & & & \\
\hline $\begin{array}{l}\text { NIL } \\
(\mathrm{X} / \\
\end{array}$ & I RATA-RATA & $-0,16$ & $-0,24$ & 0,18 & 0,01 & & & \\
\hline KES & MPULAN & TN & $\mathrm{TN}$ & $\overline{\mathrm{CN}}$ & $\mathrm{CN}$ & & & \\
\hline
\end{tabular}


Berdasarkan analisis teoritis dan analisis empiris tersebut, konsep kenyamanan di Jl. Stasiun Kereta Api Medan dan Jl. Palang Merah Medan adalah sebagai berikut:

1. Faktor Sirkulasi

Dalam sirkulasi, hal yang harus diperhatikan adalah sebagai berikut:

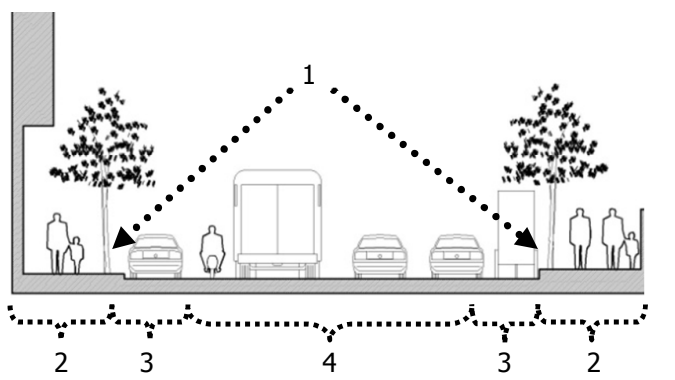

1 Perletakan furniture dan pepohonan

2 Perletakan jalur pedestrian

3 Perletakan parkir dan PKL

4 Arus kendaraan bermotor

Parkir kendaraan bermotor dan pepohonan sebagai buffering dari arus kendaraan bermotor

Gambar 2. Konsep sirkulasi di Jl. Stasiun Kereta Api Medan Jl. Palang Merah Medan

2. Faktor Iklim/kekuatan alam

Dalam mengatasi faktor iklim/kekuatan alam, hal yang perlu dilakukan sebagai berikut:

- Penanaman pepohonan berdaun rindang seperti pohon ketapang sebagai tempat berteduh bagi pejalan kaki.

- Penyediaan shelter seperti halte atau pepohonan untuk berteduh saat hujan maupun terik matahari bagi pejalan kaki yang menunggu kendaraan umum.

Pohon ketapang untuk mengatasi terik matahari
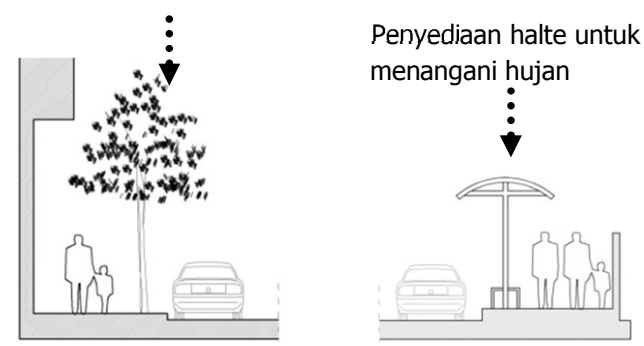

Gambar 3. Konsep iklim/kekuatan alam di Jl. Stasiun Kereta Api Medan Jl. Palang Merah Medan

\section{Faktor Kebisingan}

Faktor yang mempengaruhi kenyamanan akibat kebisingan adalah suara bising dari kendaraan bermotor atau transportasi umum, pedagang kaki lima $(P K L)$, dan parkir liar di Jl. Stasiun Kereta Api Medan tersebut. Hal yang perlu dilakukan adalah penataan parkir liar sepeda motor, penataan pedagang kaki lima (PKL), dan penyediaan buffering untuk suara transportasi umum seperti kereta api.

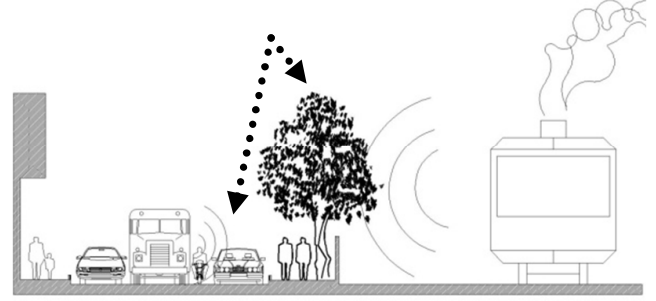

Gambar 4. Konsep kebisingan di Jl. Stasiun Kereta Api Medan Jl. Palang Merah Medan 
4. Faktor Aroma/bau-bauan

Dalam mengatasi permasalahan aroma/bau-bauan, hal yang harus dilakukan yaitu penanaman semak, perdu, dan pepohonan untuk mengurangi polusi dan bau. Selain itu perlu pula penyediaan bak sampah dengan desain yang mampu mengurangi bau sampah seperti tempat sampah dengan penutup

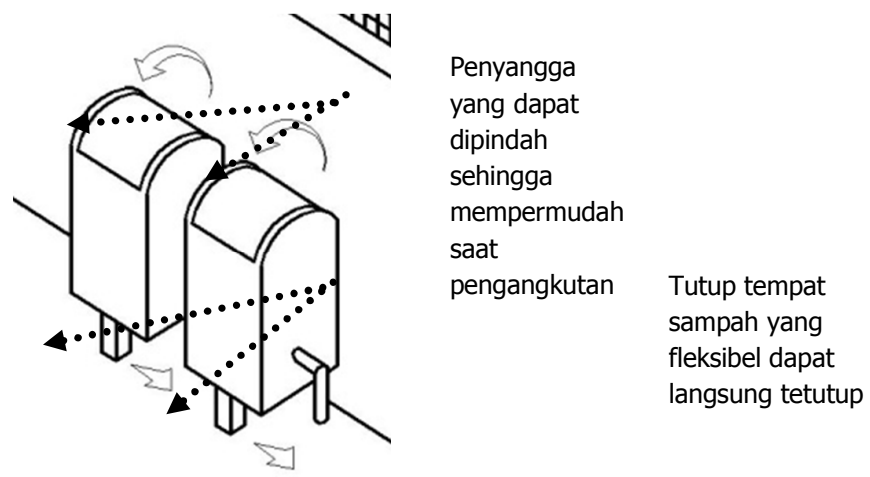

Gambar 5. Konsep aroma/bau-bauan di Jl. Stasiun Kereta Api Medan Jl. Palang Merah Medan

\section{Faktor Bentuk}

Dalam mengatasi permasalahan faktor bentuk, perlu penataan permukaan trotoar dengan paving block sehingga lebih mudah pemasangan dan perawatannya, selain itu paving block dapat menyerap air lebih cepat, tidak licin, dan warna yang tidak memantulkan cahaya. Beberapa jenis paving block yang dapat digunakan adalah sebagai berikut:

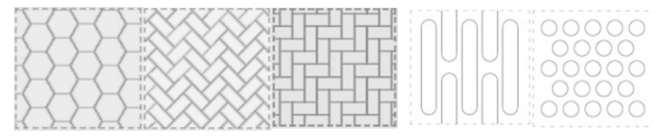

Pola-pola paving block dapat pula dipadukan dengan keramik khusus kaum difabel

Gambar 6. Konsep bentuk di Jl. Stasiun Kereta Api Medan Jl. Palang Merah Medan

6. Faktor Keamanan

Dalam faktor keamanan hal yang perlu dilakukan ialah pemasangan kerb untuk membatasi antara pejalan kaki dan kendaraan bermotor. Sehingga pejalan kaki aman dari bahaya terserempet kendaraan bermotor.

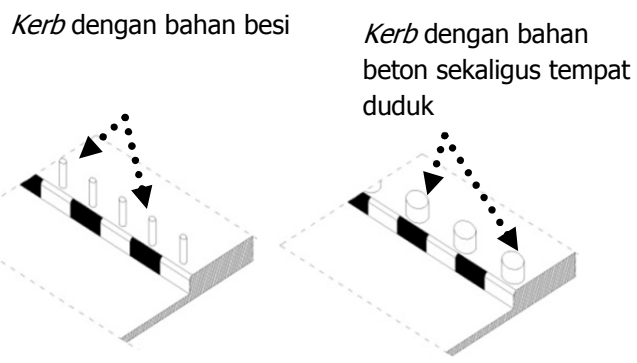

Gambar 7. Konsep keamanan di Jl. Stasiun Kereta Api Medan Jl. Palang Merah Medan 


\section{Faktor Kebersihan}

Untuk mengatasi permasalahan kebersihan, perlu disediakan bak-bak sampah setiap jarak 15 m- 20 m. Selain itu drainase untuk air hujan juga perlu disediakan sehingga tidak terjadi genangan air di sepanjang jalan dan jalur pedestrian.

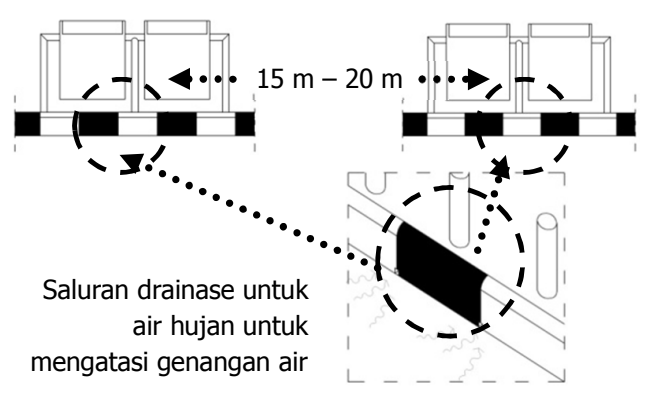

Gambar 8. Konsep kebersihan di Jl. Stasiun Kereta Api Medan Jl. Palang Merah Medan

\section{Faktor Keindahan}

Dalam faktor keindahan, hal-hal yang perlu diperhatikan adalah bentuk dan elemen perkerasan, susunan tanaman dan elemen perkerasan, warna tanaman dan elemen perkeraan, serta fasilitas pendukung sirkulasi manusia.

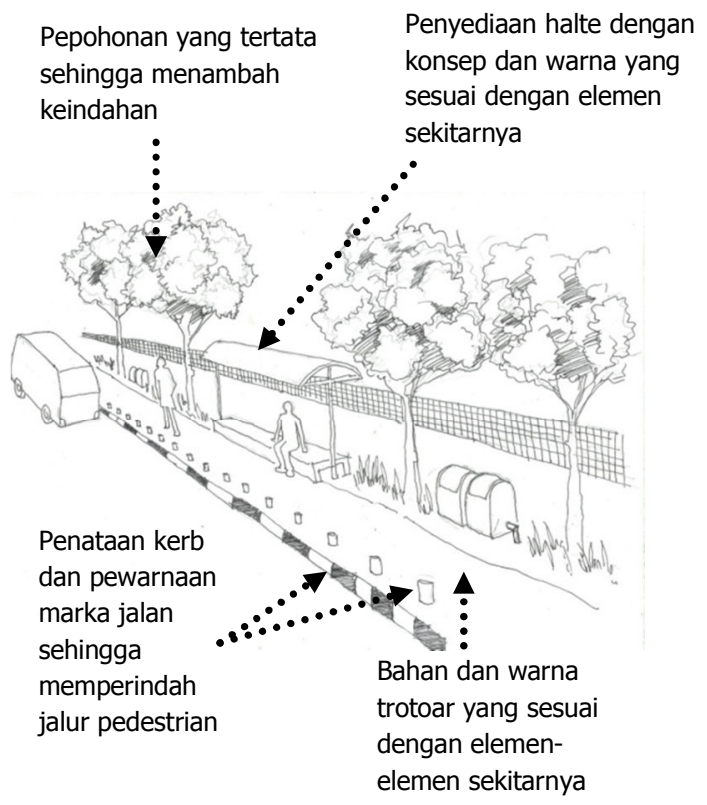

Gambar 9. Konsep keindahan di Jl. Stasiun Kereta Api Medan Jl. Palang Merah Medan

\section{Kesimpulan}

Jalur pedestrian merupakan bagian dari manusia yang tidak akan pernah bisa lepas dalam setiap aktivitasnya. Karena aktivitas manusia pada umumnya selalu dilakukan dengan berjalan kaki, baik didalam suatu bangunan, maupun di luar bangunan. Secara khusus di kawasan perkotaan, jalur pedestrian merupakan bagian dari kota yang sangat penting sehingga perlunya memperhatikan kenyamanan jalur pedestrian tersebut karena melalui jalur pedestrian inilah setiap tempat dapat terhubungkan. 
Demikian pula halnya di Jl. Stasiun Kereta Api Medan dan Jl. Palang Merah Medan. Kenyamanan jalur pedestrian merupakan hal yang harus diperhatikan perencanaan, perancangan dan perawatannya karena melihat begitu pentingnya jalur pedestrian ini bagi masyarakat kota Medan bahkan dari luar kota maupun daerah sekitar kota Medan.

Namun hal yang terjadi di Jl. Stasiun Kereta Api Medan dan Jl. Palang Merah Medan adalah kurang terawatnya trotoar di sepanjang kedua ruas jalan tersebut, hal ini terlihat dari rusak dan berlubangnya trotoar sehingga membahayakan pejalan kaki. Selain itu, tidak terdapatnya fasilitas yang mendukung aktivitas pejalan kaki yang melintas juga mengurangi kenyamanan dari jalur pedesrtian di kedua ruas jalan tersebut.

Berdasarkan hasil analisis teoritis dan analisis empiris (kuestioner) yang dilakukan, terdapat ketidaknyamanan terhadap beberapa faktor kenyamanan di Jl. Stasiun Kereta Api Medan dan Jl. Palang Merah Medan tersebut.

Permasalahan utama terjadi pada faktor aroma atau bau-bauan dan faktor kebersihan. Hal ini disebabkan oleh tidak adanya tempat pembuangan sampah di sepanjang Jl. Stasiun Kereta Api Medan dan Jl. Palang Merah Medan sehingga pejalan kaki yang melintas merasa sangat tidak nyaman. Permasalahan lainnya terdapat pada faktor iklim atau kekuatan alam, kebisingan, dan bentuk. Permasalahan pada faktor bentuk terjadi disebabkan oleh tidak adanya shelter untuk berteduh dan kurang maksimalnya keberadaan pepohonan untuk berteduh. Permasalahan kebisingan secara umum terjadi di Jl. Stasiun Kereta Api Medan, hal ini dikarenakan keberadaan transportasi umum yakni kereta api di sebelah jalan tersebut sehingga pada waktu tertentu terjadi suara yang mengganggu para pejalan kaki. Permasalahan faktor bentuk terjadi disebabkan oleh rusaknya jalur trotoar diakibatkan oleh tidak terawatnya trotoar di $\mathrm{Jl}$. Stasiun Kereta Api Medan dan Jl. Palang Merah Medan. Berdasarkan analisa yang dilakukan, faktor sirkulasi dan keamanan tidak mengalami permasalahan, namun perlu ditingkatkan fungsi dari kedua faktor tersebut sehingga kenyamanan dari kedua faktor tersebut dapat dioptimalkan.

\section{Daftar Pustaka}

Anggriani, Niniek, (2009). Pedestrian ways dalam perancangan kota.Yayasan Humaniora, Klaten.

Gallion, Arthur B., FAIA dan Simon Eisner, (1992). Pengantar perancangan kota, Penerbit Erlangga, Jakarta.

Gulo, W., (2009). Metodologi penelitian, Grasindo, Jakarta.

Mirsa, Rinaldi, (2012). Elemen tata ruang kota, Graha Ilmu, Yogyakarta.

Nazir, Moh., Ph. D, (1988). Metode penelitian, Ghalia Indonesia, Jakarta.

Rapoport, Amos, (1977). Human Aspect of Urban Form, Penerbit Erlangga, Jakarta

Shirvani, Hamid, (1985). The urban design proscess, Ombak, Yogyakarta.

Snyder, James C. dan Anthony J. Catanese, (1985). Pengantar arsitektur, Penerbit Erlangga, Jakarta. 


\title{
KAJIAN KUALITAS JALUR PEJALAN KAKI DITINJAU DARI SEGI VISUAL
}

\author{
(Studi Kasus : Jalur Pejalan Kaki Di Jalan Guru Patimpus Medan) \\ Dionesia Devita Sari ${ }^{(1)}$, Anna L Rahmawati ${ }^{(2)}$, Immanuel Perangin-angin ${ }^{(3)}$ \\ (1) Mahasiswa, Prodi Arsitektur, Fakultas Teknik, Universitas Katolik Santo Thomas Sumatera Utara \\ (2) Staff Pengajar, Prodi Arsitektur, Fakultas Teknik, Universitas Katolik Santo Thomas Sumatera Utara \\ Email: lucyra7011661@gmail.com \\ (3) Staff Pengajar, Prodi Arsitektur, Fakultas Teknik, Universitas Katolik Santo Thomas Sumatera Utara
}

\begin{abstract}
The existence of pedestrian paths in the Merdeka Field area is increasing but the visual quality of the area itself is decreasing, one of which is the pedestrian pathway in the Medan Guru Patimpus road. So the main problem to be explored in this research is how the quality of the pedestrian pathway is in the path of Guru Patimpus when viewed from the visual side. The research method used is descriptive qualitative method. Data that has been collected is analyzed by using the evaluation parameters based on theory. This study found that the quality of pedestrian paths on Jalan Guru Patimpus was quite good in the application of visual terminals and visual frames and was not good at applying the dynamics of road boundary constraints.
\end{abstract}

Keywords : Pedestrian, Visual quality

\begin{abstract}
Abstrak
Keberadaan jalur pejalan kaki atau pedestrian di kawasan Lapangan Merdeka semakin meningkat tetapi kualitas visual kawasan/jalur pejalan kaki itu sendiri semakin menurun salah satunya adalah jalur pejalan kaki di jalan Guru Patimpus Medan. Maka yang menjadi permasalahan pokok untuk ditelusuri dalam penelitian ini adalah bagaimana kualitas jalur pejalan kaki yang berada di jalan Guru Patimpus jika dilihat dari sisi visual. Metode penelitian yang digunakan adalah metode kualitatif deskriptif. Data yang telah dikumpul dianalisa dengan menggunakan parameter penilaian berdasarkan teori. Penelitian ini menemukan bahwa kualitas jalur pejalan kaki di Jalan Guru Patimpus cukup baik dalam penerapan terminal visual dan bingkai visual serta kurang baik dalam penerapan dinamika pembatas ruang jalan.
\end{abstract}

Kata-kunci : Pedestrian, visual.

\section{Pendahuluan}

Jalur pejalan kaki atau sering disebut pedestrian dalam perancangan kota merupakan elemen penting.Perencanaan jalur pejalan kaki tidak hanya merupakan upaya peningkatan kenyaman saja namun perlu akan kualitas visual akan keberadaan jalur pejalan kaki. Lebih dari itu elemen pejalan kaki yang mimiliki kualitas visual memberikan kesan nyaman bagi pejalan kaki yang melintas dijalur pejalan kaki.Dari seminar kelompok sebelumnya telah dilakukan observasi terhadap kawasan Lapangan Merdeka dan sekitarnya.Keberadaan fasilitas pejalan kaki di kawasan Lapangan Merdeka semakin meningkat tetapi kualitas visual kawasan/jalur pejalan kaki itu sendiri semakin menurun.

Jalur pejalan kaki pada umumnya terbentuk karena adanya kebutuhan dari kegiatan sehari-hari seperti di pagi hari saat anak-anak pergi sekolah,ibu-ibu pergi kepasar atau saat para pekerja/karyawan menuju tempat kerjanya. Sebuah sistem pedestrian yang baik mengurangi ketergantungan dari kendaraan bermotor di area pusat kota, menambah pengguna pejalan di pusat kota, memperbesar lingkungan yang mengajukan dalam sistem skala manusia, menciptakan beberapa aktivitas retail, dan akhirnya membantu untuk meningkatkan kualitas udara (Shirvani, 1985 : 31).Kualitas berhubungan 
dengan pertimbangan-pertimbangan dasar untuk pemeliharaan maupun estetika (Kim W.Todd,1987: 88.Kebanyakan dari pengalaman seseorang akan tempat adalah visual demikian dengan sirkulasi Secara visual jalur pejalan kaki membutuhkan : (Eckbo,Urban Lanscape Design dalam Makalah Seminar Angkatan XIX,1999 :18).

1. Terminal Visual

2. Bingkai Visual

3. Dinamika Pembatas Ruang Jalan

Berdasarkan latar belakang yang telah diuraikan, maka yang menjadi permasalahan pokok untuk ditelusuri dalam penelitian ini adalah : bagaimana kualitas jalur pejalan kaki yang berada di jalan Guru Patimpus jika dilihat dari sisi visual.Kegiatan penelitian ini bertujuan untuk menemukan bagaimana kualitas jalur pejalan kaki di jalan Guru Patimpus jika diamati dari segi visual melalui pendekatan teori kebutuhan surkulasi secara visual.

\section{Metode Penelitian}

Metode penelitian yang digunakan adalah metode kualitatif deskriptif karena memberikan gambaran tentang latar pengamatan, orang, tindakan dan pembicaraan secara menyeluruh dalam bentuk kata-kata dan bahasa (Moleong, 2007: 4-6, 211).

\section{Metode Pengumpulan Data}

Metode pengumpulan data yang digunakan, data primer (observasi,dokumentasi hasil survei dilapangan atau arsip, disertai dengan wawancara) dan data sekunder (buku panduan teori,buku hasilhasil studi dan studi histori).

\section{Metode Analisis Data}

Analisis Data dilakukan dengan merumuskan parameter penilaian kualitas jalur pejalan kaki dari segi visual berdasarkan teori kebutuhan sirkulasi secara visual dalam memperoleh nilai kualitatif kemudian peneliti mendeskripsikan nilai kaualitaif yang diperoleh sesuai pendekatan teori yang dipakai dengan kondisi dilapangan sehingga memperoleh hasil kualitatif deskriptif.Berikut tabel parameter penilaian berdasarkan teori keburuhan sirkulasi secara visual :

Tabel 1.1 Parameter penilaian dengan pendekatan penerapan terminal visual

\begin{tabular}{|c|c|c|c|}
\hline $\begin{array}{l}\mathrm{N} \\
\mathrm{O}\end{array}$ & $\begin{array}{l}\text { Terminal } \\
\text { Visual }\end{array}$ & Kriteria Analisa & Nilai \\
\hline \multirow{4}{*}{1} & \multirow{4}{*}{$\begin{array}{l}\text { Penjajaran } \\
\text { Horizontal }\end{array}$} & $\begin{array}{l}\text { Terdapat penjajaran horizontal yang baik tetapi tidak } \\
\text { dipergunakan. }\end{array}$ & 1 \\
\hline & & $\begin{array}{l}\text { Terdapat penjajaran horizontal yang berfungsi tetapi fisik tidak } \\
\text { terlihat }\end{array}$ & 2 \\
\hline & & Terdapat penjajaran horizontal dengan kondisi fisik tidak jelas & 3 \\
\hline & & $\begin{array}{l}\text { Terdapat penjajaran horizontal yang baik dan jelas terlihat } \\
\text { oleh pengguna serta berfungsi }\end{array}$ & 4 \\
\hline \multirow{4}{*}{2} & \multirow{4}{*}{$\begin{array}{l}\text { Penjajaran } \\
\text { Vertikal }\end{array}$} & Tidak baik dan tidak berguna untuk pengguna jalur & 1 \\
\hline & & Baik tetapi tidak berguna untuk pengguna jalur & 2 \\
\hline & & Fisiknya jelas,berfungsi tetapi tidak untuk jalur pejalan kaki & 3 \\
\hline & & $\begin{array}{l}\text { Baik,jelas,mudah dilihat dan berguna bagi pengguna jalur } \\
\text { pejalan kaki }\end{array}$ & 4 \\
\hline
\end{tabular}


Tabel 1.2 Parameter penilaian dengan pendekatan penerapan bingkai visual

\begin{tabular}{|c|c|c|c|}
\hline No & $\begin{array}{l}\text { Bingkai } \\
\text { Visual }\end{array}$ & Kriteria Analisa & Nilai \\
\hline \multirow[t]{4}{*}{1} & \multirow{4}{*}{ Vegetasi } & sebagai penghalang pandangan dan tidak terawat & 1 \\
\hline & & sebagai penghalang pandangan penggunaan jalur (tidak teratur) & 2 \\
\hline & & sebagai pembatas sisi jalur yang dari awal tidak direncanakan & 3 \\
\hline & & yang dari awal sudah direncanakan sebagai pembatas sisi jalur & 4 \\
\hline \multirow[t]{4}{*}{2} & \multirow{4}{*}{$\begin{array}{l}\text { Ruang } \\
\text { Terbuka }\end{array}$} & jajarang bangunan yang ruangnya diberi elemen yang monoton & 1 \\
\hline & & $\begin{array}{l}\text { elemen pembatas untuk penghalang pandangan yang tidak } \\
\text { menyenangkan }\end{array}$ & 2 \\
\hline & & bangunan yang memiliki ruang depan yang tidak monoton & 3 \\
\hline & & $\begin{array}{l}\text { Ada ruang terbuka sebagai pembatas sisi jalur yang meberi kesan } \\
\text { tidak menoton bagi pengguna jalur }\end{array}$ & 4 \\
\hline
\end{tabular}

Tabel 1.3 Parameter penilaian dengan pendekatan penerapan dinamika pembatas ruang jalan

\begin{tabular}{|c|c|c|c|}
\hline No & $\begin{array}{l}\text { Dinamika } \\
\text { Pembatas } \\
\text { Ruang Jalan }\end{array}$ & Kriteria Analisa & Nilai \\
\hline \multirow{4}{*}{1} & \multirow{4}{*}{$\begin{array}{l}\text { Garis-garis } \\
\text { kemunduran }\end{array}$} & tidak memiliki set back dengan jalur pejalan kaki & 1 \\
\hline & & $\begin{array}{l}\text { tidak ada set back tetapi drainase diberi penutup oleh perkerasan } \\
\text { sehingga pengguna jalur bisa memakai drainase sebagai jalur pejalan } \\
\text { kaki. }\end{array}$ & 2 \\
\hline & & $\begin{array}{l}\text { memiliki set back dan drainase diberi penutup oleh perkerasan } \\
\text { sehingga pengguna jalur bisa memakai drainase sebagai jalur pejalan } \\
\text { kaki. }\end{array}$ & 3 \\
\hline & & $\begin{array}{l}\text { memiliki set back dan diberi tempat tersendiri dan drainase diberi } \\
\text { penutup oleh perkerasan sehingga pengguna jalur bisa memakai } \\
\text { drainase sebagai jalur pejalan kaki. }\end{array}$ & 4 \\
\hline
\end{tabular}

Penilaian memperoleh nilai kualitatif :
Tidak Baik $=0-1$
Kurang Baik $=1-2$
Cukup Baik $=2-3$
Baik $=3-4$ 


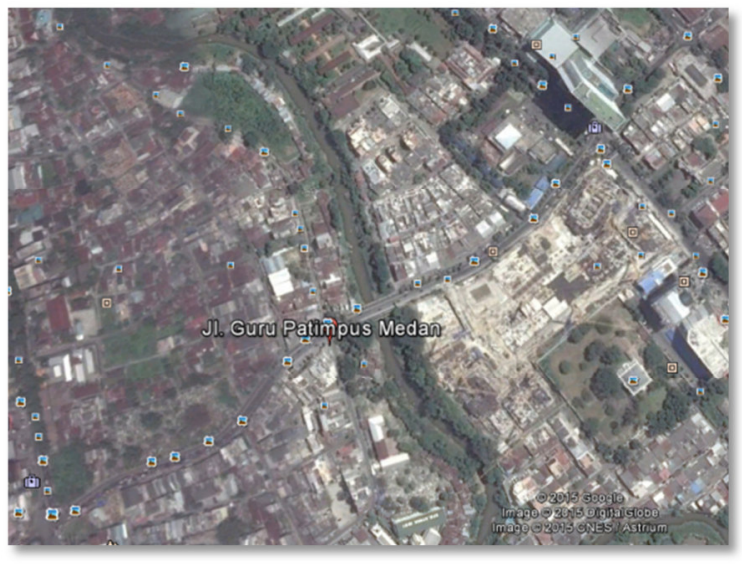

Gambar 1. Keberadaan Jalan Guru Patimpus melaui google earth.

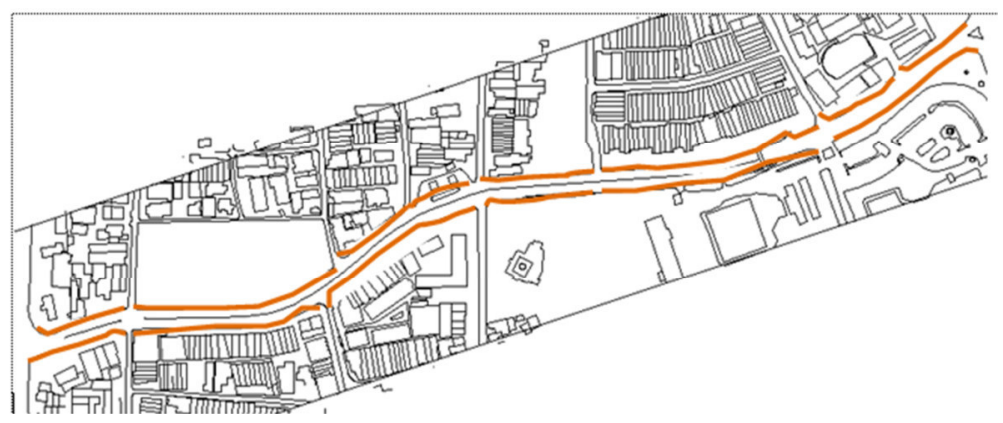

Gambar 2.Posisi jalur pejalan kaki di Jalan Guru Patimpus

\section{Analisis dan Interpretasi}

Hasil analisa dari 8 segmen jalur pejalan kaki yang berada di jalan Guru Patimpus dengan menggunakan parameter penilaian berdasarkan teori kebutuhan sirkulasi secara visual yang terdiri dari terminal visual,bingkai visual dan dinamika pembatas ruang jalan adalah:

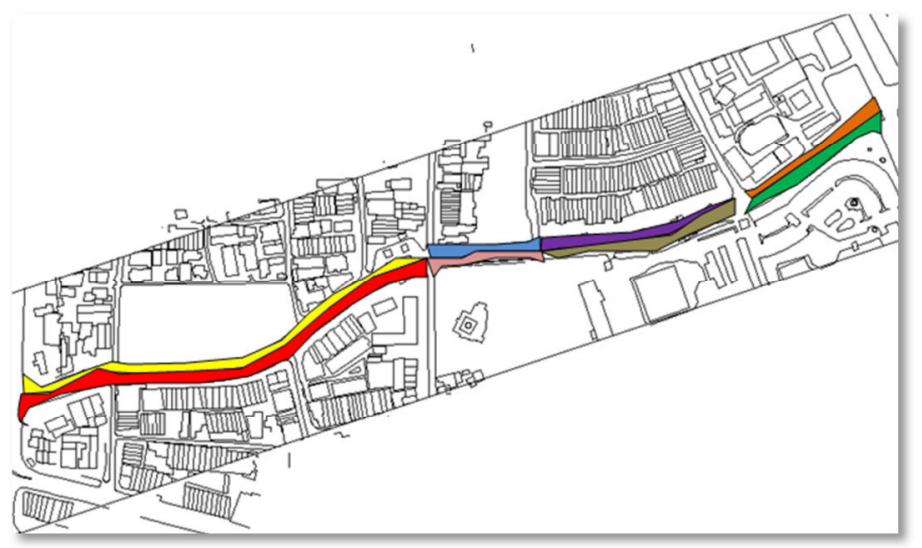

Gambar 1.3 Pembagian segmen jalur pejalan kaki di jalan Guru Patimpus 
Tabel 1.4 Parameter penilaian dengan pendekatan penerapan dinamika pembatas ruang jalan

\begin{tabular}{|c|c|c|c|}
\hline \multirow{3}{*}{ No } & \multirow{3}{*}{ Aspek Kualitas Visual } & \multicolumn{2}{|c|}{ Nilai Rata-rata } \\
\hline & & \multicolumn{2}{|c|}{$\begin{array}{c}\text { Keseluruhan } \\
\text { Segmen }\end{array}$} \\
\hline & & Sisi Kiri & $\begin{array}{c}\text { Sisi } \\
\text { Kanan }\end{array}$ \\
\hline & \multicolumn{3}{|l|}{ Terminal Visual } \\
\hline 1 & Terminal visual horizontal & 2,5 & 2,25 \\
\hline 2 & Terminal visual vertikal & 2,75 & 3,75 \\
\hline \multicolumn{4}{|c|}{ Bingkai Visual } \\
\hline 3 & Vegetasi & 2,5 & 2,0 \\
\hline 4 & Ruang terbuka & 2,25 & 1,75 \\
\hline \multicolumn{4}{|c|}{$\begin{array}{l}\text { Dinamika Pembatas Ruang } \\
\text { Jalan }\end{array}$} \\
\hline 5 & Garis-garis kemunduran & 1,5 & 1,25 \\
\hline
\end{tabular}

Maka, Jalur pejalan kaki di sisi Kiri Jl;Guru Patimpus memiliki antara lain :

- Nilai rata-rata Terminal visual horizontal di sisi kiri Jl.Guru Patimpus adalah 2,5 maka dapat disimpulkan cukup baik.

- Nilai rata-rata Terminal visual vertikal di sisi kiri Jl Guru Patimpus adalah 2,75 maka dapat disimpulkan cukup baik.

- Nilai rata-rata Vegetasi sebagai Bingkai visual di sisi Jl.Guru Patimpus adalah 2,5 maka dapat disimpulkan cukup baik.

- Nilai rata-rata Ruang terbuka sebagai Bingkai visual di sisi Jl. Guru Patimpus adalah 2,25 maka dapat disimpulkan cukup baik.

- Nilai rata-rata Dinamika pembatas ruang jalan yakni garis-garis kemunduran di sisi Jl.Guru Patimpus adalah 1,5 maka dapat disimpulkan kurang baik.

Maka, Jalur pejalan kaki di sisi Kanan Jl;Guru Patimpus memiliki antara lain :

- Nilai rata-rata Terminal visual horizontal di sisi kanan Jl.Guru Patimpus adalah 2,25 maka dapat disimpulkan cukup baik.

- Nilai rata-rata Terminal visual vertikal di sisi kanan Jl Guru Patimpus adalah 3,75 maka dapat disimpulkan baik.

- Nilai rata-rata Vegetasi sebagai Bingkai visual di sisi kanan Jl.Guru Patimpus adalah 2,0 maka dapat disimpulkan kurang baik.

- Nilai rata-rata Ruang terbuka sebagai Bingkai visual di sisi kanan Jl. Guru Patimpus adalah 1,75 maka dapat disimpulkan kurang baik.

- Nilai rata-rata Dinamika pembatas ruang jalan yakni garis-garis kemunduran di sisi kanan Jl.Guru Patimpus adalah 1,25 maka dapat disimpulkan kurang baik.

Tabel 1.5 Parameter penilaian dengan pendekatan penerapan dinamika pembatas ruang jalan

\begin{tabular}{ccc}
\hline No & Segmen & $\begin{array}{c}\text { Nilai Rata-rata Aspek } \\
\text { Kualitas Visual }\end{array}$ \\
\hline 1 & Segmen 1 & 3,0 \\
\hline 2 & Segmen 2 & 1,6 \\
\hline 3 & Segmen 3 & 2,4 \\
\hline
\end{tabular}




\begin{tabular}{lll}
4 & Segmen 4 & 2,2 \\
\hline 5 & Segmen 5 & 2,6 \\
\hline 6 & Segmen 6 & 2,6 \\
\hline 7 & Segmen 7 & 2,0 \\
\hline 8 & Segmen 8 & 1,6 \\
\hline
\end{tabular}

Maka,Nilai rata-rata aspek kualitas visual setiap segmen jalur pejalan kaki di Jl.Guru Patimpus adalah:

- $\quad$ Segmen 1 sisi kiri Jl.Guru Patimpus adalah 3,0 berarti cukup baik

- $\quad$ Segmen 2 sisi kiri Jl.Guru Patimpus adalah 1,6 berarti kurang baik

- $\quad$ Segmen 3 sisi kiri Jl.Guru Patimpus adalah 2,4 berarti cukup baik

- $\quad$ Segmen 4 sisi kiri Jl.Guru Patimpus adalah 2,2 berarti cukup baik

- $\quad$ Segmen 5 sisi kanan Jl.Guru Patimpus adalah 2,6 berarti cukup baik

- $\quad$ Segmen 6 sisi kanan JI.Guru Patimpus adalah 2,6 berarti cukup baik

- $\quad$ Segmen 7 sisi kanan Jl.Guru Patimpus adalah 2,0 berarti kurang baik

- $\quad$ Segmen 8 sisi kanan Jl.Guru Patimpus adalah 1,6 berarti kurang baik

\section{Kesimpulan}

Dari pendekatan teori kebutuhan sirkulasi secara visual untuk terminal visual dan bingkai visual pada keseluruhan jalur pejalan kaki di jalan Guru Patimpus memperoleh nilai cukup baik untuk setiap segmen, baik itu jalur di segmen kiri maupun jalur di segmen kanan tetapi untuk kebutuhan sirkulasi secara visual yaitu dinamika pembatas ruang memproleh nilai kurang baik. Dan dari semua segmen yang mendekati atau bisa dikatatakan memenuhi kebutuhan sirkulasi secara visual adalah jalur pejalan kaki di segmen 1 yang memiliki lebar pedestrian $125 \mathrm{~cm}$. Dari penelitian yang telah dilakukan pada segmen 1 dengan menggunakan pendekatan teori kebutuhan sirkulasi secara visual terlihat bahwa lebarnya suatu jalur pejalan kaki tidak menjamin kualitas visual yang dimiliki baik adanya.Hal ini terlihat akan penerapan dinamika pembatas ruang jalan yang cukup sederhana pada segmen ini dapat memberi kualitas visual tersendiri yaitu cukup baik jika dilihat dari segmen yang lainnya. Hal ini peneliti merekomendasikan untuk penelitian selanjutnya mengenai lebarnnya pedestrian tidak menjamin kualitas visual itu baik.

\section{Daftar Pustaka}

Sirvani,Hamid. (1985). The Urban Design Process. Universitas Michigan: Van Nostrand Reinhold. Eckebo,Garret. (1964). Urban Lanscape design dalam Malah Seminar Arsitektur individu angkatan XIX (1999) :Universitas Katolik St Thomas Sumatera Utara.

Todd,Kim W (1987). Tapak, Ruang dan Struktur. Bandung : Intermatra. Nazir,Moh Ph,D (2011).Metode Penelitian.Bogor :Ghalia Indonesia.

Pusat Bahasa Depdiknas. (2001).Kamus Besar Bahasa Indonesia .Jakarta : Balai Pustaka. 